\title{
Ecomorphological patterns of the fishes inhabiting the tide pools of the Amazonian Coastal Zone, Brazil
}

\author{
Bruno Eleres Soares ${ }^{1,2}$, Tiago Octavio Begot Ruffeil ${ }^{2}$ and Luciano Fogaça de Assis Montag²
}

The present study was based on the identification of the ecomorphological patterns that characterize the fish species found in tide pools in the Amazonian Coastal Zone (ACZ) in the Pará State, Brazil. Representatives of 19 species were collected during two field campaigns in 2011. The dominance, residence status, and trophic guild of each species were established, and morphometric data were obtained for up to 10 specimens of each species. A total of 23 ecomorphological attributes related to locomotion, position in the water column, and foraging behavior were calculated for the analysis of ecomorphological distance. Principal Component Analysis (PCA) was utilized for the evaluation of ecomorphological attributes that explained the variation among species. Mantel Test was used to correlate the taxonomic distance with species' morphological patterns and a partial Mantel Test to analyze the correlation among trophic guilds and ecomorphological patterns, controlling the effects of taxonomic distance among species. The analyses revealed two principal axes of the variation related to locomotion, correlated with the width of the caudal peduncle and the shape of the anal fin, as well as the influence of taxonomic distance on the ecomorphological characteristics of the different species. The dominant and resident species both presented a reduced capacity for continuous swimming. The two principal axes identified in relation to the position of the fish in the water column were correlated with the position of the eyes, the area of the pelvic fin, and body shape, with evidence of the influence of taxonomic distance on the morphology of the species. PCA grouped species with pelagic habits with benthonic ones. In the case of foraging behavior, the two principal axes formed by the analysis correlated with the size of the mouth, eye size, and the length of the digestive tract. Species of different guilds were grouped together, indicating a weak relationship between morphology and foraging behavior, and no relationship was found with taxonomic distance. The resident and dominant species in the tide pools of the ACZ present sedentary habits, with little evidence of the influence of taxonomic distance on the use of habitats or morphology, which was a poor indicator of foraging strategies, and showing that phylogenetically distant species could present similar ecomorphological patterns.

Identificamos padrões ecomorfológicos que refletem a ecologia de espécies encontradas em poças de maré na Zona Costeira Amazônica (ZCA). Indivíduos de 19 espécies foram coletados no estado do Pará durante duas expedições em 2011. Foram estabelecidas dominância, grau de residência, guildas tróficas e tomadas medidas morfométricas de até 10 indivíduos de cada espécie. Calculou-se 23 atributos ecomorfológicos relacionados à locomoção, posição e forrageio, utilizados para o cálculo da distância ecomorfológica. Foram utilizadas Análises de Componentes Principais (PCA) para avaliar que atributos ecomorfológicos explicaram a variação entre as espécies. O teste de Mantel foi utilizado para testar a correlação da distância taxonômica com a morfologia das espécies e um teste de Mantel parcial para avaliar a correlação das guildas tróficas com os padrões ecomorfológicos, controlando-se o efeito da distância taxonômica entre as espécies. Nas análises formaram-se dois eixos principais para variação em relação aos padrões de locomoção, correlacionados à largura do pedúnculo caudal e formato da nadadeira anal, ocorrendo influência da distância taxonômica entre as espécies nos padrões ecomorfológicos. Espécies dominantes e residentes apresentaram menor capacidade de natação contínua. Quanto à posição na coluna d'água, formaram-se dois eixos principais da variação, correlacionados à posição do olho, área da nadadeira pélvica e formato do corpo, ocorrendo influência da distância taxônomica entre as espécies nas dissimilaridades morfológicas. A PCA agrupou espécies de hábito pelágico com espécies de hábito bentônico. Em relação ao forrageio, formaram-se dois eixos principais da variação, correlacionados ao tamanho da boca, tamanho do olho e comprimento do trato digestório. Espécies de diferentes guildas permaneceram agrupadas, sugerindo fraca relação da morfologia com o forrageio e não houve influência da distância taxonômica nas dissimilaridades nas guildas tróficas. Espécies residentes e dominantes em poças de maré na ZCA apresentam hábito sedentário, ocorrendo pouca influência da distância taxonômica nos padrões ecomorfológicos que se referem à posição na coluna d'água e locomoção, demonstrando que espécies distantes filogeneticamente podem apresentar padrões ecomorfológicos similares, e a morfologia demonstrou-se como fraca preditora das táticas de forrageio.

Key words: Ecomorphology, habitat use, resource partitioning, intertidal zone, estuaries.

${ }^{1}$ Laboratório de Ecologia de Peixes, Departamento de Ecologia, Universidade Federal do Rio de Janeiro, 21941-972 Ilha do Fundão, Rio de Janeiro, RJ, Brazil. brunoeleres@yahoo.com.br

${ }^{2}$ Laboratório de Ecologia e Zoologia de Vertebrados, Instituto de Ciências Biológicas, Universidade Federal do Pará. Av. Bernardo Saião, s/n, 68625-150 Guamá, Belém, Pará, Brazil. tbegot@gmail.com (TOBR), montag@ufpa.br (LFAM) 


\section{Introduction}

Tide pools form micro-environments which suffer intense and constant variation in physical-chemical characteristics, such as $\mathrm{pH}$, salinity, dissolved oxygen concentrations, and temperature, in addition to being extremely dynamic, structurally, due to wave and tide action (Horn \& Gibson, 1988; Metaxas \& Scheibling, 1993). Given these unique conditions, the species found in these habitats require morphological, physiological and behavioral adaptations in order to cope with the stresses provoked by these highlydynamic, high energy environments (Filho et al., 2006).

Winemiller (1991) and Oliveira et al. (2010) have shown a close relationship between morphological adaptations and ecological characteristics, based on the notion that morphological differences between species result from the distinct selective pressures that they suffer (Beaumord \& Petrere, 1994). In other words, ecomorphology studies the relationship among morphological adaptations and ecology (Wainwright, 1996). In this context, reliable data on the functional morphology and ecological characteristics of the study species are necessary for the understanding of the relationship between the species and their environment (Breda et al., 2005).

In fishes, two complementary approaches are normally used in ecomorphological studies. The first focuses on the feeding behavior of the species based on the morphological traits related directly to feeding behavior (e.g., the position of the mouth and the length of the digestive tract), given that the composition of the diet will be related to these features (Wainwright \& Richard, 1995). The second approach is based on the analysis of habitat use and locomotion through the identification of parameters such as body height and the configuration of the fins, which reflect specific aspects of habitat structure, such as substrate types and tidal dynamics, and contribute to the partitioning of habitat use (Willis et al., 2005). The combination of these approaches permits the identification of the strategies adopted by the different species for the exploitation of spatial and trophic resources within the same environment (Deus \& Petrere, 2003).

Oliveira et al. (2010) have demonstrated a high degree of correlation between morphological characteristics and the exploitation of the resources available in the environment, whereas others have found a weak relationship between the two variables (e.g., Clifton \& Motta, 1998; Casatti \& Castro, 2006). Some studies, such as that of Gibran (2010), who analyzed nektonic coastal species in southeastern Brazil, have emphasized the need to consider the differential effects of phylogenetic and historic factors in the structuring of fish communities. This is because the characteristics presented by a species may be intrinsic to its evolutive lineage, rather than reflecting morphological adaptations to its environment. Felsenstein (1985) concluded that species are part of a phylogenetic complex, and cannot be considered to be statistically independent samples taken from a continuous distribution.

Given the divergent results obtained by some ecomorphological studies, Wolff (2012) warned against making generalizations based on the morphological characteristics of Neotropical fishes. However, if the ecomorphological tenet is not the underlying principle accounting for community structure, some factor other than morphological adaptations for specific niches must underpin community structure (Douglas \& Matthews, 1992).

Based on the ecomorphological principle, feeding behavior and habitat preferences can be interpreted from the biometric measurements used to calculate ecomorphological attributes. These attributes can be interpreted in terms of lifestyles and the types of habitat occupied (Barrela, 1989), and can provide insights into the foraging strategies and habitat preferences of the different species. As estuaries represent an important natural nursery for many fish species (Costa \& Souza-Conceição, 2009), a good working knowledge of the species that occupy these systems is fundamental to the conservation of fishery stocks. In addition, the systematic analysis of differentiated structures may provide important insights into the reliability of the ecomorphological principle. The present study aimed to (i) identify ecomorphological variables that correspond to ecological patterns related to the locomotion, position, and foraging behavior of the fish species found in the tide pools of the Amazonian Coastal Zone (ACZ), (ii) test the correspondence of the predicted ecomorphological patterns to the foraging strategies observed in the fishes present in the ACZ tide pools, (iii) verify the influence of taxonomic proximity on the ecomorphological characteristics of the fish species analyzed, and (iv) identify possible ecomorphological patterns that reflect the degree of residency of the different fish species observed in the ACZ tide pools.

\section{Material and Methods}

\section{Study area}

The tide pools selected for the present study are located on the eastern coast of Pará State, Brazil (Fig. 1), on sandy beaches with rocky outcrops appropriate for the retention of intertidal fish species (Fig. 1). The beaches were Areuá, in the município de Curuçá, Maçarico and Marieta in Salinópolis, and Algodoal and Fortalezinha in Maracanã. The Amazonian coast is distinguished from other coastal areas in Brazil by a set of unique characteristics, such as high annual rainfall (up to $3300 \mathrm{~mm}$ ), which varies considerably between rainy and dry seasons, high (above $20^{\circ} \mathrm{C}$ ) and relatively stable temperatures year-round, extensive tracts of mangrove forest, and the fluvial discharge of the Amazon River and dozens of local estuaries, which contribute to high concentrations of sediments, nutrients, and organic material in the water (Pereira et al., 2009). 


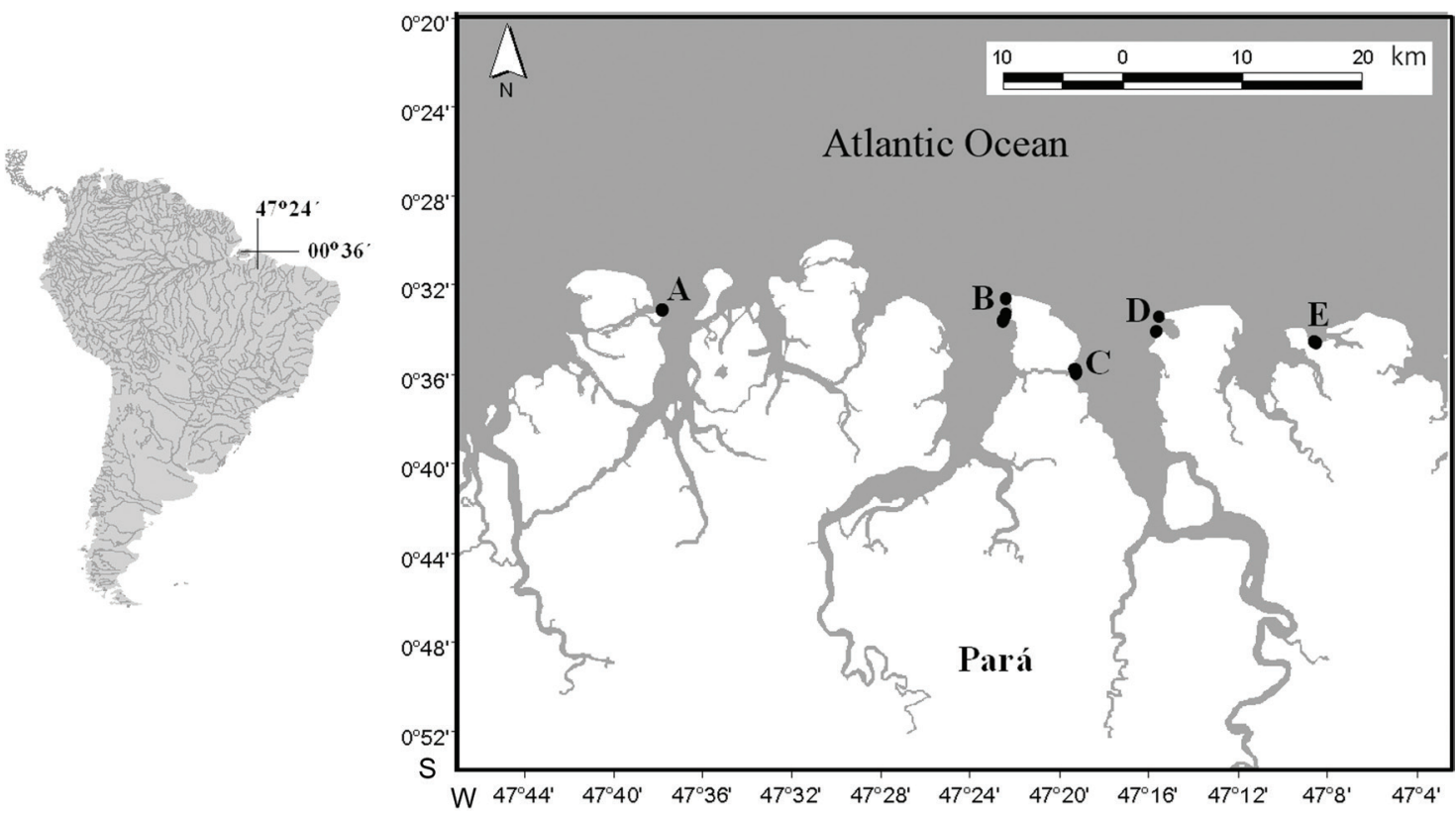

Fig. 1. Location of the tide pools sampled in 2011 on the sandy beaches of the Amazonian Coastal Zone at (A) Areuá, (B) Algodoal, (C) Fortalezinha, (D) Marieta, and (E) Maçarico.

\section{Sampling schedule}

Two campaigns were conducted for the fish collection, one in the rainy season (February, March, and April), and the second during the dry season (September, October, and November) of 2011. A total of 80 tide pools - 40 per campaign - were sampled during the daytime low spring tide. Information on tide times were obtained from the Brazilian Navy's internet page (www. mar.mil.br). Fish specimens were collected during sweeps of the tide pools with hand-nets and sieves with a $5 \mathrm{~mm}$ mesh. No fixed time limit was stipulated, but each pool was swept until no further specimens were collected for a period of at least 10 minutes.

All the specimens collected were fixed in $10 \%$ formalin and after three days, conserved in $70 \%$ ethanol. All the specimens were identified in the laboratory and subsequently deposited in the ichthyological collection of the Museu Paraense Emílio Goeldi (MPEG) in Belém, northern Brazil. The voucher numbers are shown in Table 2.

\section{Data analysis}

The species collected during the study were classified as dominant, frequent, occasional or rare, according to the system of Myers et al. (2011), which is based on the relative abundance (RA) and frequency of occurrence (FO) of each species. Species were classified as dominant when their FO was higher than 0.6, and RA was equal or above 0.3 , frequent when the $\mathrm{FO}$ value was between 0.2 and 0.6 , and RA was above 0.06 , occasional when FO was between 0.05 and 0.19 and RA was between 0.001 and 0.06 , and rare when they were recorded only once during the study.
The pattern of occurrence of the species observed in the tide pools was also evaluated based on the available literature, and classified using the scheme of Macieira \& Joyeux (2010). In this classification, resident species are found in tide pools throughout their life cycle, and often present specific adaptations for life in intertidal environments, such as the species of the families Gobiidae and Blenniidae (Horn et al., 1999). Opportunist species spend only part of their life cycle - normally as juveniles - in tide pools, while transitory species are found in this environment only occasionally or accidentally, with no specific adaptations for survival in intertidal habitats. The rare species collected during the present study were also classified as transitory.

The trophic guilds were defined based on published data on diet. Species for which no data were found were classified based on the analysis of stomach contents, with up to 10 digestive tracts being analyzed per species. The contents were examined under a stereoscopic microscope and the contents' source was identified (animal or vegetal source) and used to define the trophic guild of each fish species. Species were considered to be (a) omnivores, when the stomach contents contained at least $30 \%$ algae or fragments of plants, (b) herbivores, when algae or fragments of plants were the only material found, and (c) carnivores, when animals were the dominant items.

Morphometric measurements were obtained from up to 10 specimens of each identified species. Measurements of the body, fins, head, and eye were taken using a pair of $150 \mathrm{~mm}$ digital calipers with a precision of $0.1 \mathrm{~mm}$, always from the right side of the specimen. Fin areas were calculated from outlines drawn on greaseproof paper, which were scanned and fed into the AutoCAD software for the calculation of the areas $\left(\mathrm{mm}^{2}\right)$. 
Table 1. Ecomorphological indices adopted in the present study and their respective formulae and ecological interpretation. Codes: area of the anal fin (AAF), area of the caudal fin (ACF), area of the pectoral fin (APCF), area of the pelvic fin (APVF), breadth of the caudal peduncle (BCP), breadth of the mouth (BM), head breadth (HB), head height (HH), head length (HL), height of the caudal fin (HCF), height of the caudal peduncle (HCP), height of the dorsal fin (HDF), height of the eye (HE), height of the midline (HML), height of the mouth (HM), length of the anal fin (LAF), length of the caudal peduncle (LCP), length of closed snout (LCS), length of the digestive tract (LDT), length of open mouth (LOM), length of the pectoral fin (LPCF), length of the pelvic fin (LPVF), maximum body breadth (MBB), maximum body height (MBH), standard length (SL).

\begin{tabular}{|c|c|c|c|}
\hline Ecomorphological indices & Formula & Related to & Ecological implications \\
\hline $\begin{array}{l}\text { Relative length of the caudal } \\
\text { peduncle }\end{array}$ & $\mathrm{RLCP}=\mathrm{LCP} / \mathrm{SL}$ & Locomotion & $\begin{array}{l}\text { High values indicate species with good swimming capacity } \\
\text { (Winemiller, 1991). }\end{array}$ \\
\hline $\begin{array}{l}\text { Relative height of the caudal } \\
\text { peduncle }\end{array}$ & $\mathrm{RHCP}=\mathrm{HCP} / \mathrm{MBH}$ & Locomotion & $\begin{array}{l}\text { Low values indicate a reduced potential for maneuverability } \\
\text { (Winemiller, 1991). }\end{array}$ \\
\hline $\begin{array}{l}\text { Relative width of the caudal } \\
\text { peduncle }\end{array}$ & $\mathrm{RWCP}=\mathrm{BCP} / \mathrm{HB}$ & Locomotion & $\begin{array}{l}\text { Higher values indicate a better capacity for continuous swimming } \\
\text { (Winemiller, 1991). }\end{array}$ \\
\hline Relative area of the dorsal fin & $\mathrm{RADF}=\mathrm{HDF} / \mathrm{SL}^{2}$ & Locomotion & $\begin{array}{l}\text { Dorsal fins with a greater area provide better stability (Gosline, } \\
\text { 1971). }\end{array}$ \\
\hline Relative area of the caudal fin & $\mathrm{RACF}=\mathrm{ACF} / \mathrm{SL}^{2}$ & Locomotion & $\begin{array}{l}\text { Caudal fins with a greater area are associated with continuous and } \\
\text { active swimming (Balon et al., 1986). }\end{array}$ \\
\hline Aspect ratio of the caudal fin & $\mathrm{ARCF}=\mathrm{HCF}^{2} / \mathrm{ACF}$ & Locomotion & $\begin{array}{l}\text { High values are typical of active and continuous swimmers (Balon } \\
\text { et al., 1986). }\end{array}$ \\
\hline Relative area of the anal fin & $\mathrm{RAAF}=\mathrm{AAF} / \mathrm{SL}^{2}$ & Locomotion & $\begin{array}{l}\text { Higher values indicate greater maneuverability and stability } \\
\text { (Breda, 2005). }\end{array}$ \\
\hline Aspect ratio of the anal fin & $\mathrm{ARAF}=\mathrm{LAF}^{2} / \mathrm{AAF}$ & Locomotion & $\begin{array}{l}\text { High values indicate a greater capacity for forward and backward } \\
\text { movements (Breda, 2005). }\end{array}$ \\
\hline Relative area of the pectoral fin & $\mathrm{RAPCF}=\mathrm{APCF} / \mathrm{SL}^{2}$ & Locomotion & $\begin{array}{l}\text { High values are associated with slow swimming or fishes that } \\
\text { inhabit turbulent waters (Watson \& Balon, 1984). }\end{array}$ \\
\hline Aspect ratio of the pectoral fin & $\mathrm{ARPCF}=\mathrm{LPCF} / \mathrm{APCF}$ & Locomotion & $\begin{array}{l}\text { High values are associated with migratory species or fishes that } \\
\text { swim continuously (Wainwright et al., 2002). }\end{array}$ \\
\hline Compression index & $\mathrm{CI}=\mathrm{MBH} / \mathrm{HB}$ & Position & $\begin{array}{l}\text { High values indicate species that inhabit lenthic environments } \\
\text { (Watson \& Balon, 1984). }\end{array}$ \\
\hline Depression índex & $\mathrm{DI}=\mathrm{HML} / \mathrm{MBH}$ & Position & $\begin{array}{l}\text { High values indicate species associated with environments near the } \\
\text { bottom (Watson \& Balon, 1984). }\end{array}$ \\
\hline Position of the eye & $\mathrm{PE}=\mathrm{HE} / \mathrm{HH}$ & Position & $\begin{array}{l}\text { High values indicate dorsally-positioned eyes, which are normally } \\
\text { found in benthic fishes (Pouilly et al., 2003). }\end{array}$ \\
\hline Relative area of the pelvic fin & $\mathrm{RAPVF}=\mathrm{APCF} / \mathrm{SL}^{2}$ & Position & $\begin{array}{l}\text { Higher values are found in benthic species and lower values in } \\
\text { pelagic fishes (Breda, 2005). }\end{array}$ \\
\hline Aspect ratio of the pelvic fan & $\mathrm{ARPVF}=\mathrm{LPVF}^{2} / \mathrm{APVF}$ & Position & $\begin{array}{l}\text { Higher values indicate pelagic habits, while lower values indicate } \\
\text { benthic behavior (Breda, 2005). }\end{array}$ \\
\hline Relative length of the head & $\mathrm{RLH}=\mathrm{HL} / \mathrm{SL}$ & Foraging & $\begin{array}{l}\text { High values indicate fishes that capture larger prey, and are expected } \\
\text { in piscivorous species (Pouilly et al., 2003). }\end{array}$ \\
\hline Relative height of the head & $\mathrm{RHH}=\mathrm{HH} / \mathrm{MBH}$ & Foraging & $\begin{array}{l}\text { Higher values indicate fishes that capture larger prey and are } \\
\text { expected in piscivores (Willis et al., 2005). }\end{array}$ \\
\hline Relative breadth of the head & $\mathrm{RBH}=\mathrm{HB} / \mathrm{MBB}$ & Foraging & $\begin{array}{l}\text { High values are expected in piscivores or fishes that capture larger } \\
\text { prey (Willis et al., 2005). }\end{array}$ \\
\hline Relative height of the mouth & $\mathrm{RHM}=\mathrm{HM} / \mathrm{SL}$ & Foraging & $\begin{array}{l}\text { High values may indicate fishes that feed on larger prey (Willis et } \\
\text { al., 2005). }\end{array}$ \\
\hline Relative width of the mouth & $\mathrm{RWM}=\mathrm{BM} / \mathrm{SL}$ & Foraging & $\begin{array}{l}\text { High values indicate fishes that feed on larger prey (Winemiller, } \\
\text { 1991). }\end{array}$ \\
\hline Protrusion index & $\mathrm{PI}=\mathrm{LOM} / \mathrm{LCS}$ & Foraging & $\begin{array}{l}\text { Higher values are found in fishes that captures smaller prey } \\
\text { (Willis et al., 2005). }\end{array}$ \\
\hline Relative area of the eye & $\mathrm{RAE}=\Pi^{*}(\mathrm{HE} / 2)^{2} / \mathrm{SL}^{2}$ & Foraging & $\begin{array}{l}\text { Index related to the detection of food items and the use of vision } \\
\text { during predatory behavior (Pouilly et al., 2003). }\end{array}$ \\
\hline Relative length of the digestive tract & $\mathrm{RLDT}=\mathrm{LDT} / \mathrm{SL}$ & Foraging & $\begin{array}{l}\text { Higher values are associated with omnivorous or herbivorous diets } \\
\text { (Boyle \& Horn, 2006). }\end{array}$ \\
\hline
\end{tabular}

A total of 25 different morphometric measurements were taken. These measurements were used to calculate 23 ecomorphological indices (Table 1).
The ecomorphological characteristics were analyzed using a linear correlation in order to eliminate traits that are strongly correlated. It was chosen to eliminate few highly 


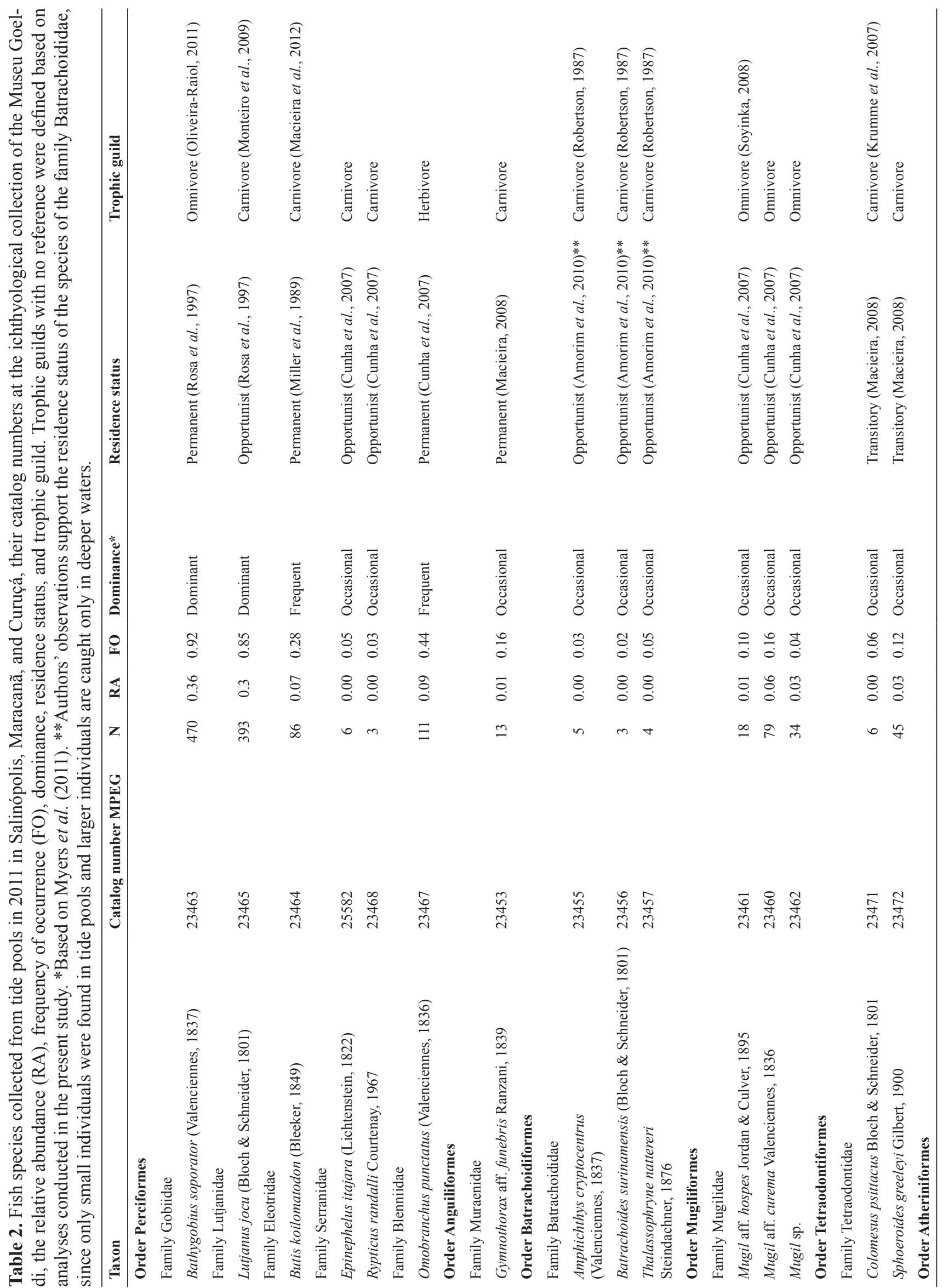


correlated variables due to the fact that multicollinearity may cause problems in multiple regression models (El-Dereny \& Rashwan, 2011). Following the elimination of these traits, a Principal Components Analysis (PCA) was used to identify the ecomorphological attributes that respond best to the morphological variation seen among species, considering only the values with a correlation of over $70 \%$ with the two principal explanatory axes. This approach permitted the identification of the components that most contributed to the variation in the data, and also allowing a reduction in the number of variables.

In order to decide which components (axes) should be maintained for interpretation, Broken-stick cut-off values were used, and the data were run in the $\mathrm{R}$ routine. Groups of species were determined visually in the ordination diagram of the first two axes of principal component analysis and their scores were compared with one-way ANOVA, given that the data satisfied the assumptions required for a parametric test. The null hypothesis was that the groups have no influence on the score of the group formed by the PCA axes, considering a 5\% significance level, as used by Petry et al. (2003).

The possible effects of the taxonomic relationships among the different species were examined using the simple Mantel test based on a routine for the comparison of matrices run in the NTSYS 2.1 program. For this procedure, a triangular matrix containing the Euclidian distances between each pair of species was compared with a second triangular matrix of taxonomic distance. This taxonomic matrix was based on the species classification, following the approach proposed by Gibran (2010), in which pairs of species that belong to the same genus are allocated to class 1, those in different genera, but the same family to class 2 , members of the same suborder, but different families to class 3 , members of different suborders but the same order were assigned to class 4 , species belonging to the same supraorder but different orders, to class 5 , and species from different supraorders were designated class 6 . The Mantel test was used to analyze the data on the relative position of the species in the water column, locomotion, and foraging behavior, with the coefficients being considered significant when $\mathrm{p}<0.05$ in order to verify the effect of taxonomic relationships on ecomorphological distance. Since Mantel test analyzes the correlation among two distances matrices (Legendre \& Fortin, 2010) (ecomorphological distance vs. taxonomic distance), we adopted as null hypothesis the lack of a taxonomic signal on the ecomorphology of the study species.

The effectiveness of the morphological attributes related to foraging behavior as predictors of the feeding behavior of the species was evaluated using a partial Mantel test to analyze the correlation between trophic guilds and the ecomorphological distance between species, with the effects of taxonomic distance being removed. The trophic guild distance matrix was based on scores of 1 for pairs of species belonging to the same guild (e.g., omnivore vs. omnivore) 
and 2 for species belonging to different guilds (e.g., omnivore vs. carnivore). Partial Mantel test analyzes the correlation among two distance matrices (ecomorphological distance $v s$. trophic guild distance) controlling the effect of a third one (taxonomic distance). This analysis correlates the residuals of the regression of ecomorphological and trophic guild distance matrices with the taxonomic distance matrix as independent variable (Smouse et al., 1986; Oliveira et al., 2010).

The influence of the residence status of the fish species found in the tide pools was also evaluated using a partial Mantel test, with the effects of the taxonomic distance between species. For this, matrices of Euclidean distances were established for each pair of species based on their ecomorphological attributes (locomotion, position in the water column, and foraging behavior) together with a triangular matrix which took the taxonomic distance (as described above) into account. This allowed the effects of residence status on ecomorphological patterns to be analyzed independently of the taxonomic proximity of the species. The matrix of residence status was based on scores of 1 for species classified with the same status (e.g., permanent resident $v s$. permanent resident) and 2 for species with different classifications (e.g., permanent resident $v s$. transitory).

\section{Results}

A total of 1,302 specimens were captured belonging to 19 fish species and 13 families in nine orders were recorded (Table 2). The dominant species included both permanent residents, such as Bathygobius soporator (Valenciennes, 1837), and opportunists, as Lutjanus jocu (Bloch \& Schneider, 1801), and in fact, few of the permanent residents are dominant in the tide pool environment.

Most of the tide pool species collected in the present study (Table 2) were classified as omnivores $(32 \%)$ or carnivores (58\%), with only two herbivorous species - Omobranchus punctatus (Valenciennes, 1836) and Engraulidae gen. which represent $10 \%$ of the species sampled. Most (47\%) of the species were classified as opportunists, with $53 \%$ of the species being allocated to the permanent and transitory categories.

The analysis of the ecomorphological attributes related to locomotion found a high degree of correlation with a number of different variables, of which the following were eliminated from subsequent analyses (variables eliminated shown in bold type, followed by the correlated variables and respective coefficients): $\mathbf{R L C P}$ (RWCP $=0.84$; RACF $=0.85)$, RHCP $($ ARAF $=-0.79), \mathbf{R A C F}(\mathrm{RWCP}=0.76$; ARAF $=-0.84)$ and $\mathbf{R A A F}(\mathrm{RADF}=0.84 ; \mathrm{RAPCF}=0.80)$. No correlation was found in the case of vertical position in the water column, which enabled the analysis to include all the parameters measured, while one variable - RBH $(\mathrm{RWM}=0.77)-$ was eliminated from the analysis of foraging strategies.
In the case of locomotion, the PCA was based on six ecomorphological indices, and resulted in two statistically significant axes based on the broken-stick model. The first two axes explained $66.618 \%$ of the total variation in the ecological space related to the locomotion of the species. The highest correlation coefficients were selected for the interpretation of the data (Table 3).

The species with the lowest scores on axis 1 had the highest aspect ratios for the anal fin, which permits precise forward and backward movements. Species with the highest scores on axis 2 have well-developed caudal peduncles, which indicate good maneuverability and an ability to swim continuously.

The ordination of the data resulted in three groups (Fig. 2; axis $1, \mathrm{~F}=24.387$, d.f. $=16, \mathrm{p}<0.001$; axis $2, \mathrm{~F}=24.387$, d.f. $=16, \mathrm{p}<0.001)$ : the first group is characterized by narrower caudal peduncles and lower anal fin aspect ratios, with a reduced capacity for forward and backward movement, such as the gobioids, Butis koilomatodon (Bleeker, 1849) and Bathygobius soporator. The second group was formed by species with intermediate ARAF scores and high RWCP values, which indicate that the species swim continuously. This group includes the mugilids and tetraontids, as well as the species Atherinella cf. brasiliensis (Quoy \& Gaimard, 1824) and Engraulidae gen. The third group isolates the species Gymnothorax funebris (Ranzani, 1840), which has a low RWCP score and a high ARAF value, which indicates that the species does not swim continuously, but is capable of efficient forward and backward movement. It is interesting to note that the resident species are concentrated in groups 1 and 3, which are characterized by a reduced capacity for continuous swimming, while the dominant species were all included in group 1. Ecological interpretations of the ecomorphological indices were based on hypotheses and remain to be tested.

Table 3. Pearson correlation coefficients $(r)$ obtained for the first two axes of the Principal Components Analysis (PCA) for six ecomorphological indices related to locomotion in the 19 species analyzed. The indices with the highest correlation coefficients (shown in bold type) were selected for interpretation. Codes: Relative width of the caudal peduncle (RWCP); Relative area of the dorsal fin (RADF); Aspect ratio of the caudal fin (ARCF); Aspect ratio of the anal fin (ARAF); Relative area of the pectoral fin (RAPCF); Aspect ratio of the pectoral fin (ARPCF).

\begin{tabular}{lcc}
\hline Ecomorphological indices & $r$ Axis 1 & $r$ Axis 2 \\
\hline RWCP & 0.277 & $\mathbf{0 . 8 2 2}$ \\
RADF & 0.566 & -0.669 \\
ARCF & 0.633 & -0.277 \\
ARAF & $\mathbf{- 0 . 7 6 4}$ & -0.544 \\
RAPCF & 0.693 & -0.394 \\
ARPCF & 0.631 & 0.289 \\
\% Explanation & 37.689 & 28.929 \\
\hline
\end{tabular}




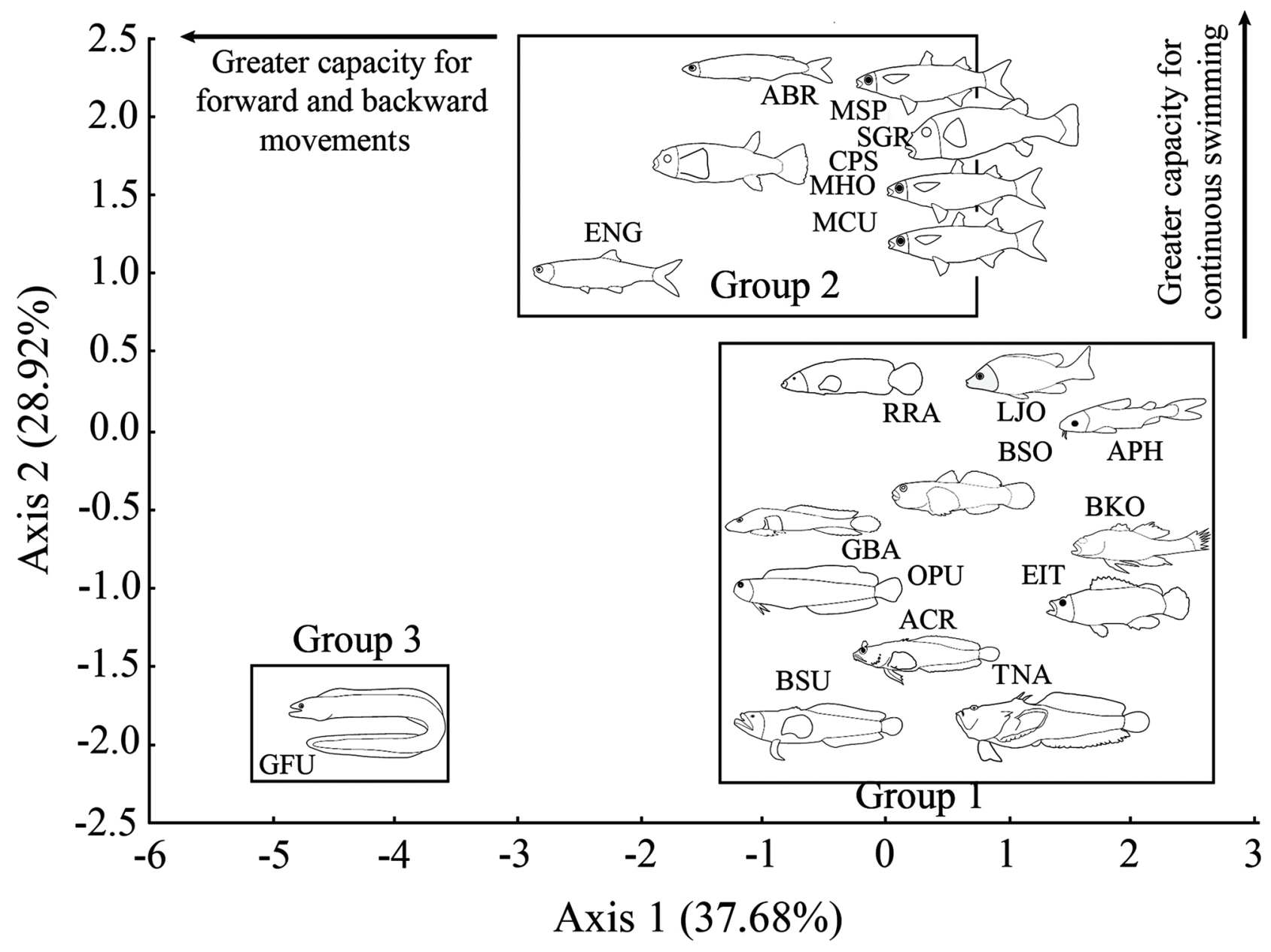

Fig. 2. Principal Components Analysis (PCA) for the six ecomorphological indices related to locomotion in the 19 fish species collected from tide pools on the Amazonian Coastal Zone in 2011. Hypotheses concerning the interpretation of the ecomorphological indices highly correlated with the principal axes. Codes: Atherinella cf. brasiliensis (ABR); Amphichthys cryptocentrus (ACR); Amphiarius phrygiatus (APH); Bathygobius soporator (BSO); Batrachoides surinamensis (BSU); Butis koilomatodon (BKO); Colomesus psittacus (CPS); Epinephelus itajara (EIT); Engraulidae gen. (ENG); Gobiesox barbatulus (GBA); Gymnothorax aff. funebris (GFU); Lutjanus jocu (LJO); Mugil aff. curema (MCU); Mugil aff. hospes (MHO); Mugil sp. (MSP); Omobranchus punctatus (OPU); Rypticus randalli (RRA); Sphoeroides greeleyi (SGR); Thalassophryne nattereri (TNA).

In the case of the position of the species in the water column, the Principal Components Analysis (PCA) identified two explanatory axes based on the broken-stick model, which accounted for $58.822 \%$ of the total variation in ecomorphological space. The highest correlation coefficients between the first and second axes were selected for interpretation (Table 4).

The species with the highest values on axis 1 have flattened bodies and dorsally-located eyes, which are characteristic of bottom-living fishes. Lower values along axis 2 indicate laterally compressed species which are probably adapted to environments with slow currents, whereas high values indicate a large relative area of the pelvic fin, which is correlated with the occupation of benthic habitats.
Table 4. Pearson correlation coefficients $(r)$ obtained for the first two axes of the Principal Components Analysis (PCA) for the five ecomorphological indices related to the position of the 19 species in the water column. The indices with the highest correlation coefficients (shown in bold type) were selected for interpretation. Codes: Compression index (CI); Depression index (DI); Position of the eye (PE); Relative area of the pelvic.fin (RAPVF); Aspect ratio of the pectoral fin (ARPVF).

\begin{tabular}{lll}
\hline Ecomorphological indices & $r$ Axis 1 & $r$ Axis 2 \\
\hline CI & -0.400 & $\mathbf{0 . 7 6 6}$ \\
DI & 0.722 & 0.374 \\
PE & $\mathbf{0 . 8 5 6}$ & 0.044 \\
RAPVF & 0.0132 & $\mathbf{0 . 7 8 5}$ \\
ARPVF & 0.348 & 0.243 \\
\% Explanation & $30.727 \%$ & $28.095 \%$ \\
\hline
\end{tabular}


The ordered data formed three distinct groups (Fig. 3; axis $1, \mathrm{~F}=21.557$; d.f. $=16 ; \mathrm{p}<0.001$; axis $2, \mathrm{~F}=12.606$, d.f. $=16, p=0.001)$. The first group contained species with flattened bodies and dorsal eyes, such as Omobranchus punctatus and two batrachoidid species, which are adapted for bottom environments. The second group includes species with flattened bodies and/or high relative area of the pelvic fin, which are characteristics of species that live close to the benthic environment, such as Bathygobius soporator and Gobiesox barbatulus Starks, 1913. The third group is composed of species with laterally compressed bodies and lateral eyes, which inhabit environments with slow currents.

With regard to feeding, the PCA formed two statistically significant axes based on the broken-stick model, which explain $60.756 \%$ of the total variation in the ecomorphological space.
The highest correlation coefficients were selected for the interpretation of the data (Table 5).

The species with the highest scores on the first axis are characterized by relatively high mouths (RHM) and relative head length (RLH), both of which are related to potential prey size. In the case of the second axis, the species with the lowest scores present relatively long digestive tracts (RLDT) and large eyes (RAE), with the former variable being related to feeding habits, and the latter to visual foraging behavior.

It is interesting to note that, in this analysis, the engraulid species remains isolated from all other species (Fig. 4) due to the high RLDT and RAE values, which indicate that the species forages visually and it feeds from vegetal sources (planktonic herbivore). The other species present lower RLDT and RAE values, forming three distinct groups in addition to that of

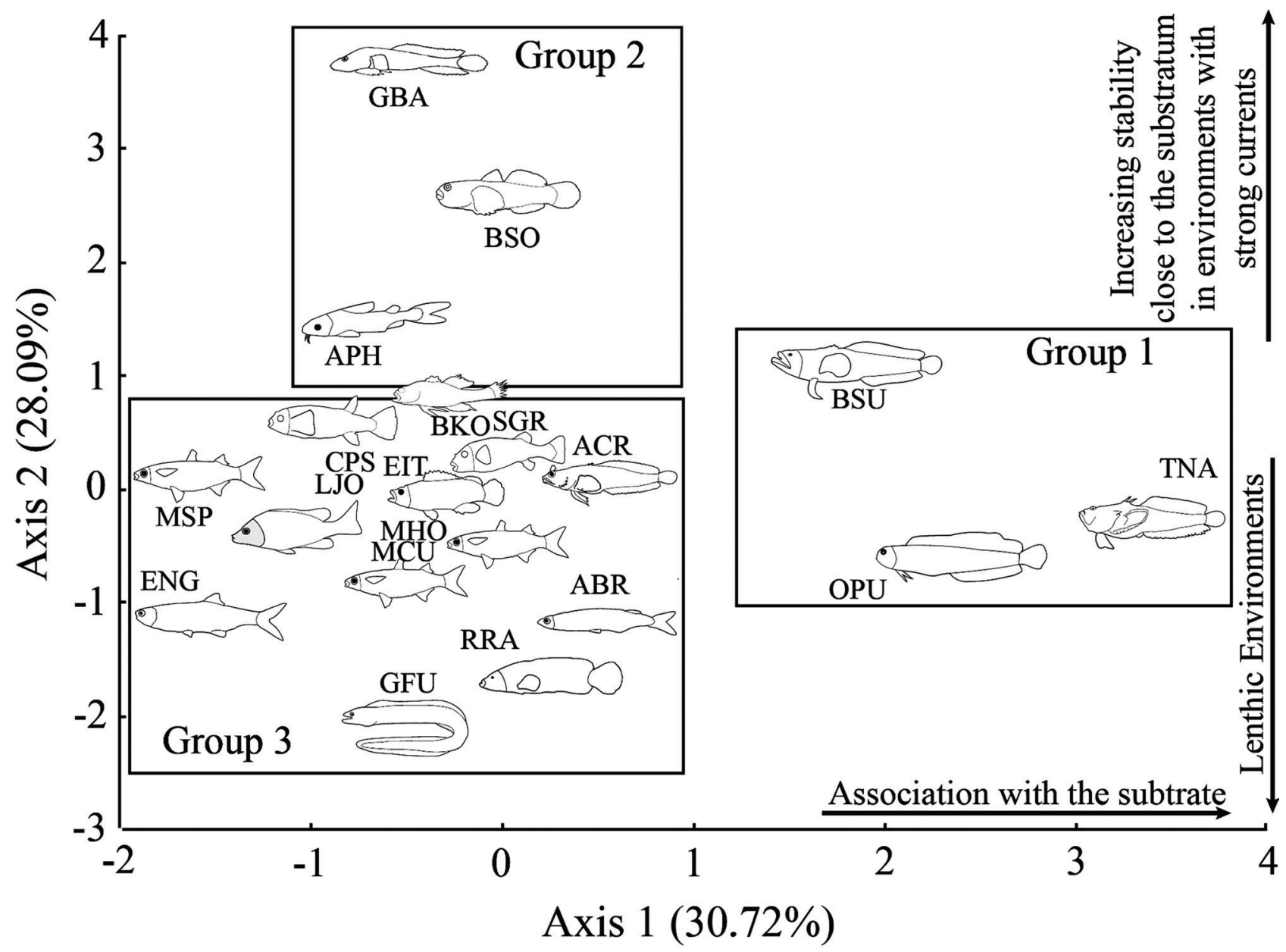

Fig. 3. Principal Components Analysis (PCA) of six ecomorphological indices related to the position of the species in the water column, based on the morphometric measurements of 19 fish species collected from tide pools on the Amazonian Coastal Zone in 2011. Hypotheses concerning the interpretation of the ecomorphological indices highly correlated with the principal axes. Codes: Atherinella cf. brasiliensis (ABR); Amphichthys cryptocentrus (ACR); Amphiarius phrygiatus (APH); Bathygobius soporator (BSO); Batrachoides surinamensis (BSU); Butis koilomatodon (BKO); Colomesus psittacus (CPS); Epinephelus itajara (EIT); Engraulidae gen. (ENG); Gobiesox barbatulus (GBA); Gymnothorax aff. funebris (GFU); Lutjanus jocu (LJO); Mugil aff. curema (MCU); Mugil aff. hospes (MHO); Mugil sp. (MSP); Omobranchus punctatus (OPU); Rypticus randalli (RRA); Sphoeroides greeleyi (SGR); Thalassophryne nattereri (TNA). 
Table 5. Pearson correlation coefficients $(r)$ obtained for the first two axes of the Principal Components Analysis (PCA) for seven ecomorphological indices related to feeding behavior in the 19 species analyzed. The indices with the highest correlation coefficients (shown in bold type) were selected for interpretation. Codes: Relative length of the head (RLH); Relative height of the head (RHH); Relative height of the mouth (RHM); Relative width of the mouth (RWM); Protrusion index (PI); Relative length of the digestive tract (RLDT); Relative area of the eye (RAE).

\begin{tabular}{lll}
\hline Ecomorphological indices & $r$ axis 1 & $r$ axis 2 \\
\hline RLH & $\mathbf{0 . 8 6 0 1}$ & -0.2113 \\
RHH & 0.5881 & 0.0816 \\
RHM & 0.8114 & -0.333 \\
RWM & 0.6967 & 0.189 \\
PI & 0.5426 & 0.2413 \\
RLDT & -0.2846 & $\mathbf{- 0 . 7 8 1 6}$ \\
RAE & 0.0922 & $\mathbf{- 0 . 8 7 8 9}$ \\
\% Explanation & 37.333 & 23.423 \\
\hline
\end{tabular}

Engraulidae gen. (Axis 1, $\mathrm{F}=19.743$, d.f. $=15, \mathrm{p}<0.001$; Axis $2, F=80.469$, d.f. $=15, p<0.001)$. One of these groups is made up of non-herbivorous species with relatively long heads and high mouths, indicating an ability to capture prey of larger size. These species include Bathygobius soporator and Butis koilomatodon. The second group is also non-herbivorous, with lower RLH and RHM values, indicating the capture of smaller prey. These species include the puffer fish Colomesus psittacus (Bloch \& Schneider, 1801) and the moray eel Gymnothorax funebris. The third group is characterized by moderate CRTH values and high CRB and RHM values. These species include Lutjanus jocu and Epinephelus itajara (Lichtenstein, 1822).

A significant correlation was found between the morphological features related to locomotion presented by the different species and their taxonomic relationships (Mantel test: $r=0.28 ; p<0.01$ ). Similar results were obtained in relation to positional behavior (Mantel test: $r=0.29 ; p<0.01$ ), although no correlation was found between the ecomorphological features related to foraging behavior and the taxonomic relationships of the study species (Mantel test; $r=0.09 ; p=0.17$ ). The partial Mantel test also indicated that the ecomorphological variables related to foraging strategies are not good predictors of the trophic guild occupied by the species $(r=0.12 ; \mathrm{p}=0.13)$. The partial Mantel test (taxonomic proximity excluded) found no correlation between residence status and the ecomorphological features related to position $(\mathrm{r}=0.11 ; \mathrm{p}=0.08)$, locomotion $(\mathrm{r}=$ $0.02 ; \mathrm{p}=0.44)$ or foraging strategy $(\mathrm{r}=-0.07 ; \mathrm{p}=0.84)$.

\section{Discussion}

Morphology reflects the trophic potential of a fish species and its ability to survive in specific habitats, and can thus be used to predict its lifestyle (Wootton, 1994; Gibran, 2007).
This is the basis of ecomorphological theory, which is founded on the functional analysis of the morphological attributes of a species in the context of its ecological characteristics, related to both foraging behavior and the occupation of different substrates (Beaumord \& Petrere, 1994).

In the case of morphological features related to locomotion, the most abundant species found in the tide pools have a limited capacity for continuous swimming. These species includes the frillfin goby (Bathygobius soporator), the invasive Butis koilomatodon and Omobranchus punctatus (Soares et al., 2011, 2012), as well as the juvenile Lutjanus jocu. This condition is associated with a more sedentary lifestyle and is characteristic of the resident species, although it is also found in non-residents, such as L. jocu and Epinephelus itajara.

Body shape is one of the primary traits analyzed in ecomorphological studies, with the compression and depression indices being commonly used in studies of microhabitat differentiation (Barreto, 2005). Fishes with high depression indices are typically found in high energy habitats, where their flattened bodies provide greater contact with the substrate and, thus, greater stability (Kerfoot-Jr \& Schaefer, 2006; Pagotto et al., 2011). Differences in these indices provide the basis for vertical stratification, which is referred herein as the position in the water column. This is one of the principal forms of resource partitioning found in fish communities (Watson \& Balon, 1984).

In the tide pools of the Amazonian coastal zone, however, a relatively weak relationship was found between this index and the ecological characteristics of the species, given that the pelagic species (Atherinella $\mathrm{cf}$. brasiliensis and Mugil sp.) were grouped together with the benthic ones (B. koilomatodon and L. jocu).

Ecomorphological theory predicts that species with similar morphological characteristics of the digestive tract will have similar diets and occupy the same trophic guilds. However, in a comparative analysis of the diets of chaetodontids, Motta (1988) concluded that morphology was not a good indicator of trophic guild. In the present study, the grouping together of herbivores, carnivores, and omnivores indicates a weak relationship between morphology and diet. The relatively long digestive tract observed in the engraulid species correctly diagnosed the species as a herbivore.

There is a clear need for further data on the diet of Bathygobius soporator, which is considered to be omnivorous with a tendency for carcinophagy (shrimp-eating). However, Oliveira-Raiol (2011) reinforced the need to confirm whether the species consumes algae systematically or accidentally. One plausible explanation for this may be that the foraging behavior of this species affects its trophic ecology, in which case, this behavioral variable may be more important than the species' morphology, as shown by Schmitt \& Coyer (1982) in their study of two marine embiotocid fishes. In this study, the 


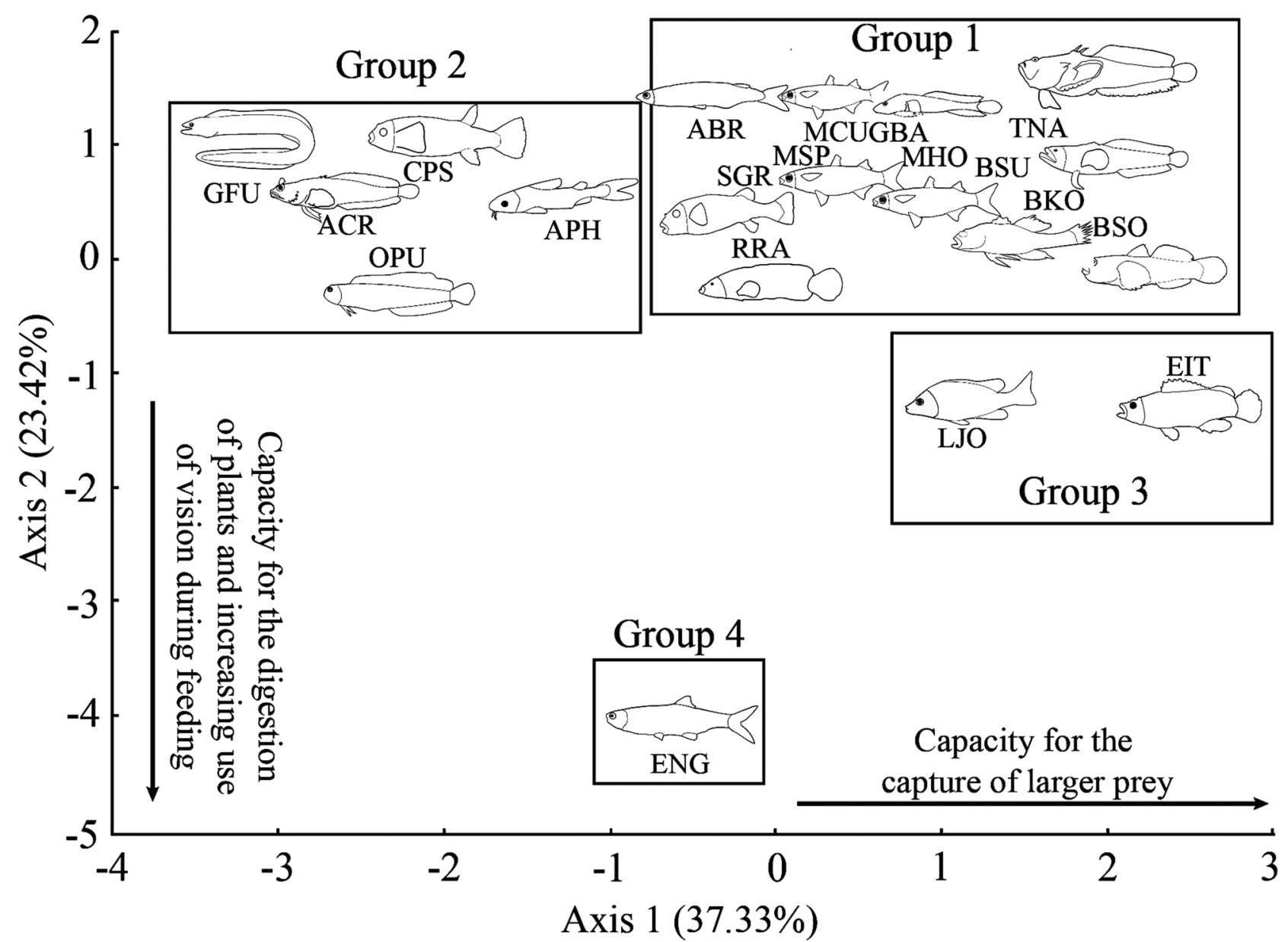

Fig. 4. Principal Components Analysis (PCA) based on the seven ecomorphological indices related to the feeding of 19 fish species collected from tide pools on the Amazonian Coastal Zone in 2011. Hypotheses concerning the interpretation of the ecomorphological indices highly correlated with the principal axes. Codes: Atherinella cf. brasiliensis (ABR); Amphichthys cryptocentrus (ACR); Amphiarius phrygiatus (APH); Bathygobius soporator (BSO); Batrachoides surinamensis (BSU); Butis koilomatodon (BKO); Colomesus psittacus (CPS); Epinephelus itajara (EIT); Engraulidae gen. (ENG); Gobiesox barbatulus (GBA); Gymnothorax aff. funebris (GFU); Lutjanus jocu (LJO); Mugil aff. curema (MCU); Mugil aff. hospes (MHO); Mugil sp. (MSP); Omobranchus punctatus (OPU); Rypticus randalli (RRA); Sphoeroides greeleyi (SGR); Thalassophryne nattereri (TNA).

variables related to the size of the prey (e.g., relative height of the mouth) were not good predictors of the ecological traits of the study species. In a study of four sympatric southeastern Brazilian serranids, Gibran (2007) found that Mycteroperca acutirostris (Valenciennes, 1828), despite having a high index of relative mouth breadth, feeds on large quantities of smaller prey items.

While the morphological features related to foraging behavior overlapped between the trophic guilds, competition among the different groups may be minimized by the variation in prey size. A similar pattern of resource partitioning based on prey size was observed Gomes et al. (2003) in the fish fauna of the Anil estuary in Maranhão (Brazil).

With respect to the ecomorphological overlap of members of different trophic guilds, it is clear that morphological traits are not good predictors of the trophic structure of the species assemblage. In this respect, the results of the present study are distinct from those of Oliveira et al. (2010), who studied a freshwater fish community in southern Brazil and found considerable similarities in the morphology of the fish species in the same guild, irrespective of their taxonomic proximity. In the present study, while the morphology of the digestive tract is not a good predictor of the trophic guild of the species, the groups were segregated by the potential prey size, independently of the taxonomic relationships among the different species. This suggests that the trophic structure of the community is organized in terms of the ecomorphological characteristics of the species rather than along phylogeny distance or evolutive lineages, as observed by Pagotto et al. (2011) for a fish community in a stream in southern Brazil, which means that despite their phylogenetic distance, there are convergent ecomorphological patterns. Marrero \& Winemiller (1993) and Montaña \& Winemiller (2013) show convergent patterns in phylogenetically distant families of fishes, considering that 
species can show similar ecomorphological patterns in spite of their phylogenetic relationship.

The differentiation of niches implicit to the ecomorphological variation observed in the data reflects the structuring of niches in the community, and indicates the segregation of the use of spaces and feeding resources by the study species. Faria \& Almada (2001) also observed marked spatial segregation in intertidal environments. This ecomorphological structuring is usually regarded as evidence that interspecific competition is occurring or has occurred at some time in the past. A number of other mechanisms may lead to segregation, however, such as behavioral and anatomical differences in ancestral forms, which raises a number of doubts with regard to the role of competition in the structuring of communities (Faria \& Almada, 2001).

The taxonomic relationships among species were more closely correlated with the ecomorphological traits related to locomotion and position in the water column. While significant, these correlations were not very strong, and reinforce the value of ecomorphological analysis for the understanding of community structure, supporting the conclusion of Oliveira et al. (2010), that the distribution of species along the PCA axes is not determined simply by the taxonomic relationships among them. In this case, anatomical differences in the ancestral forms may be the most important determinants of the structure of fish communities, although the weak correlations observed in the present study indicate that other mechanisms, such as competition, are or have contributed to spatial and trophic segregation.

The results of the present study reinforce the conclusion that the morphological characteristics of the species are related to the use of the habitats in which they are found, given that these relationships could be verified in the tide pools of the Amazonian coast based on known distribution patterns. However, only a relatively weak relationship was found in the case of the morphological adaptations for feeding, as found in other ecomorphological studies (Motta, 1988; Casatti \& Castro, 2006). This may be related primarily to a lack of behavioral data appropriate for the discrimination of the trophic guilds, which was also a problem in the present study. Nevertheless, the evidence presented in this study indicates that ecomorphological attributes play a clear role in the structuring of habitat use in the tide pools of the Amazonian coastal zone.

Taxonomic distance also played a role in the observed ecomorphological patterns, albeit with low levels of correlation. While this confirms that phylogeny plays a role in the structuring of the tide pool fish communities, the low correlation indicates clearly that other mechanisms also contribute to this structure, reflecting the integration of a series of other factors, such as ecomorphology, phylogeny, behavior, competition. No systematic variation in ecomorphological characteristics was found between resident, opportunist or transitory species.
Based on the results of the present study, further investigation is required in order to understand more fully the ecomorphological patterns of fish communities, in particular the relationship between morphology and both phylogeny and the behavioral characteristics of the different species. Alternative adaptation hypothesis could explain some of the ecomorphological patterns and should be investigated in future researches, and the use of broad feeding guilds may be affecting the interpretation of the ecomorphological structure. In addition, more detailed studies of closely-related species would provide important insights into the role of phylogeny in the determination of patterns of resource use (dietary and spatial).

\section{Acknowledgments}

We are grateful to the Universidade Federal do Pará (UFPA) for providing the infrastructure for the laboratory analyses, CNPq for the undergraduate stipend (BES) and FAPESPA for the masters stipend (TOBR). We would also like to thank local residents of the study area for logistic support and assistance during specimen collection and the personnel of the UFPA Vertebrate Zoology and Ecology Laboratory for their support during fieldwork, data analysis, and the preparation of this manuscript. This study was supported by the PROPESP/UFPA (\#05/2009) financial scheme through the PADRC/CAPES/FAPESPA recent-doctor support program.

\section{Literature Cited}

Amorim, M. C. P., J. M. Simões, P. J. Fonseca \& V. C. Almada. 2010. Patterns of shelter usage and social aggregation by the vocal Lusitanian toadfish. Marine Biology, 157: 495-503.

Araújo, F. G. 1988. Distribuição, abundância relativa e movimentos sazonais de bagres marinhos (Siluriformes, Ariidae) no estuário da lagoa dos Patos (RS), Brasil. Revista Brasileira de Zoologia, 5: 509-543.

Balon, E. K., S. S. Crawford \& A. Lelek. 1986. Fish communities of the Upper Danube River (Germany, Austria) prior to the new Rhein-Main-Donau connection. Environmental Biology of Fishes, 15: 243-271.

Barreiros, J. P., Á. Bertoncini, L. Machado, M. Hostim-Silva \& R. S. Santos. 2004. Diversity and seasonal changes in the ichthyofauna of rocky tidal pools from Praia Vermelha and São Roque, Santa Catarina. Brazilian Archives of Biology and Technology, 47: 291-299.

Barrella, W. 1989. Estrutura da comunidade de peixes da bacia do rio Jacaré Pepira (SP) em diferentes biótopos. Unpublished M.Sc. Thesis, Universidade Estadual de Campinas, Campinas, 198p.

Barreto, A. P. 2005. Características ecomorfológicas relacionadas à alimentação e ao uso do micro-hábitat em quatro espécies de Characiformes no Rio Morato - Guaraqueçaba, PR. Unpublished Ph.D Dissertation, Universidade Federal do Paraná, Curitiba, 109p.

Beaumord, A. C. \& M. Petrere Jr. 1994. Fish communities of manso River, Chapada dos Guimarães, MT, Brazil. Acta Biologica Venezuelica, 15: 21-35.

Boyle, K. \& M. H. Horn. 2006. Comparison of feeding guild structure and ecomorphology of intertidal fish assemblages from central California 
and central Chile. Marine Ecology Progress Series, 319: 65-84.

Breda, L. 2005. Ecomorfologia de Astyanax altiparanae, Moenkhausia intermedia, Roeboides paranensis e Serrasalmus marginatus (Osteichthyes-Characidae) da planície alagável do alto rio Paraná, Brasil: variação inter e intra-específica. Unpublished Ph.D. Dissertation, Universidade Estadual de Maringá, Maringá, 33p.

Breda, L, E. F. de Oliveira \& E. Goulart. 2005. Ecomorfologia de locomoção de peixes com enfoque para espécies neotropicais. Acta Scientarum (Biological Sciences), 27: 371-381.

Casatti, L. \& R. M. C. Castro. 2006. Testing the ecomorphological hypothesis in a headwater riffles fish assemblage of the rio São Francisco, southeastern Brazil. Neotropical Ichthyology, 4: 203-214.

Clifton, K. B. \& J. P. Motta. 1998. Feeding morphology, diet and ecomorphological relationships among five Caribbean labrids (Teleostei, Labridae). Copeia, 1998: 953-966.

Costa, M. D. P. \& J. M. Souza-Conceição. 2009. Composição e abundância de ovos e larvas de peixes na baía da Babitonga, Santa Catarina, Brasil. Pan-American Journal of Aquatic Sciences, 4: 372-382.

Cunha, F. E. A., C. Monteiro-Neto \& M. C. Nottingham. 2007. Temporal and spatial variations in tidepools fish assemblages of the northeast coast of Brazil. Biota Neotropica, 7: 111-118.

Deus, C. P. \& M. Petrere. 2003. Seasonal diet shifts of seven fish species in an Atlantic rainforest stream in southeastern Brazil. Brazilian Journal of Biology, 63: 579-588.

Douglas, M. E. \& W. J. Matthews. 1992. Does morphology predict ecology? Hypothesis testing within a freshwater stream fish assemblage. Oikos, 65: 213-224.

El-Dereny, M. \& N. I. Rashwan. 2011. Solving multicollinearity problem using ridge regression methods. International Journal of Contemporary Mathematical Sciences, 6: 585-600.

Faria, C. \& V. Almada. 2001. Microhabitat segregation in three rocky intertidal fish species in Portugal: does it reflect interspecific competition? Journal of Fish Biology, 58: 145-159.

Felsenstein, J. 1985. Phylogenies and the comparative method. The American Naturalist, 125: 1-15.

Filho, J. S. R., D. V. Busman, A. P. Viana, A. M. Gregório \& D. M. Oliveira. 2006. Macrofauna bentônica de zonas entre-marés não vegetadas do estuário do rio Caeté, Bragança, Pará. Boletim do Museu Paraense Emílio Goeldi (Ciências Naturais), 1: 85-96.

Gibran, F. Z. 2007. Activity, habitat use, feeding behavior, and diet of four sympatric species of Serranidae (Actinopterygii: Perciformes) in southeastern Brazil. Neotropical Ichthyology, 5: 387-398.

Gibran, F. Z. 2010. Habitat partitioning, habits and convergence among coastal nektonic fish species from the São Sebastião Channel, southeastern Brazil. Neotropical Ichthyology, 8: 299-310.

Gomes, L. N., J. R. Pinheiro-Júnior \& N. M. Piorski. 2003. Aspectos ecomorfológicos da comunidade de peixes do estuário do rio Anil, Ilha de São Luís - MA. Boletim do Laboratório de Hidrobiologia, 16: 29-36.

Gosline, W. A. 1971. Functional morphology and classification of teleostean fishes. Honolulu, University Press of Hawaii.

Horn, M. H. \& R. N. Gibson. 1988. Intertidal fishes. Scientific American, 258: 54-60.

Horn, M. H., K. L. M. Martin \& M. A. Chotkowski (Eds.). 1999. Intertidal Fishes: Life in two worlds. San Diego, Academic Press.

Kerfoot-Jr, J. R. \& J. F. Schaefer. 2006. Ecomorphology and habitat utilization of Cottus species. Environmental Biology of Fishes, 76: 1-13.
Krumme, U., H. Keuthen, U. Saint-Paul \& W. Villwock. 2007. Contribution to the feeding ecology of the banded puffer fish Colomesus psittacus (Tetraodontidae) in north Brazilian mangrove creeks. Brazilian Journal of Biology, 67: 383-392.

Legendre, P. \& M. J. Fortin. 2010. Comparison of the Mantel test and alternative approaches for detecting complex multivariate relationships in the spatial analysis of genetic data. Molecular Ecology Resources, 10: 831-844.

Macieira, R. M. 2008. Estrutura de comunidade e distribuição espacial dos peixes das poças de maré em um recife do Atlântico sudoeste, Brasil. Unpublished M.Sc. Dissertation, Universidade Federal do Espírito Santo, Vitória, 67p.

Macieira, R. M. \& J. C. Joyeux. 2011. Distribution patterns of tidepool fishes on a tropical flat reef. Fishery Bulletin, 109: 305-315.

Macieira, R. M., T. Giarrizzo, J. L. Gasparini \& I. Sazima. 2012. Geographic expansion of the invasive mud sleeper Butis koilomatodon (Perciformes: Eleotridae) in the western Atlantic Ocean. Journal of Fish Biology, 81: 308-313.

Marrero, C. \& K. O. Winemiller. 1993. Tube-snouted gymnotiform and mormyriform fishes: convergence of a specialized foraging mode in teleosts. Environmental Biology of Fishes, 38: 299-309.

Metaxas, A. \& R. E. Scheibling. 1993. Community structure and organization of tidepools. Marine Ecology, 98: 187-198.

Miller, P. J., J. Wright \& P. Wongrat. 1989. An indo-pacific goby (Teleostei: Gobioidei) from West Africa, with systematic notes on Butis and related eleotridine genera. Journal of Natural History, 23: 311-324.

Montaña, C. G. \& K. O. Winemiller. 2013. Evolutionary convergence in Neotropical cichlids and Neartic centrarchids: evidence from morphology, diet, and stable isotope analysis. Biological Journal of the Linnean Society, 109: 146-164.

Monteiro, D. P., T. Giarrizzo \& V. Isaac. 2009. Feeding ecology of juvenile dog snapper Lutjanus jocu (Bloch and Schneider, 1801) (Lutjanidae) in intertidal mangrove creeks in Curuçá estuary (Northern Brazil). Brazilian Archives of Biology and Technology, 52: 1421-1430.

Motta, P. J. 1988. Functional morphology of the feeding apparatus of ten species of Pacific butterflyfishes (Perciformes, Chaetodontidae): an ecomorphological approach. Environmental Biology of Fishes, 22: 39-67.

Myers, M. C., J. Wagner \& C. Vaughan. 2011. Long-term comparison of the fish community in a Costa Rica rocky shore marine reserve. Revista de Biologia Tropical, 59: 233-246.

Oliveira, E. F., E. Goulart, L. Breda, C. V. Minte-Vera, L. R. S. Paiva \& M. R. Vismara. 2010. Ecomorphological patterns of the fish assemblage in a tropical floodplain: effects of trophic, spatial and phylogenetic structures. Neotropical Ichthyology, 8: 569-586.

Oliveira-Raiol, R. D. 2011. Ecologia alimentar e reprodutiva do muré Bathygobius soporator (Valenciennes, 1837) na Zona Costeira Amazônica. Unpublished M.Sc. Dissertation, Universidade Federal do Pará, Belém, 52p.

Pagotto, J. P. A, E. Goulart, E. F. Oliveira \& C. B. Yamamura. 2011. Trophic ecomorphology of Siluriformes (Pisces, Osteichthyes) from a tropical stream. Brazilian Journal of Biology, 71: 469-479.

Pereira, L. C. C., J. A. Dias, J. A. Carmo \& M. A. Polette. 2009. A Zona costeira amazônica brasileira. Revista da Gestão Costeira Integrada, 9: 3-7.

Petry, A. C., A. A. Agostinho \& L. C. Gomes. 2003. Fish assemblages of tropical floodplain lagoons: exploring the role of connectivity in a dry year. Neotropical Ichthyology, 1: 111-119. 
Pires, T. H. S. \& F. Z. Gibran. 2011. Intertidal life: field observations on the clingfish Gobiesox barbatulus in south-eastern Brazil. Neotropical Ichthyology, 9: 233-240.

Pouilly, M., F. Lino, J. G. Bretenoux \& C. Rosales. 2003. Dietarymorphological relationships in a fish assemblage of the Bolivian Amazonian floodplain. Journal of Fish Biology, 62: 1137-1158.

Rocha, A. A. F., E. C. Silva-Falcão \& W. Severi. 2008. Alimentação das fases iniciais do peixe-rei Atherinella brasiliensis (Atherinopsidae) no estuário do Rio de Jaguaribe, Itamaracá, PE. Revista Brasileira de Ciências Agrárias, 3:365-370.

Rosa, R. S., I. L. Rosa \& L. A. Rocha. 1997. Diversidade da ictiofauna de poças de maré da praia do Cabo Branco, João Pessoa, Paraíba, Brasil. Revista Brasileira de Zoologia, 14: 201-212.

Robertson, D. R. 1987. Responses of two coral reef toadfishes (Batrachoididae) to the demise of their primary prey, the sea urchin Diadema antillarum. Copeia, 1987: 637-642.

Schmitt, R. J. \& J. A. Coyer. 1982. The foraging ecology of sympatric marine fish in the genus Embiotoca (Embiotocidae): Importance of foraging behavior in prey size selection. Oecologia, 55: 369-378.

Smouse, P. E., J. C. Long \& R. R. Sokal. 1986. Multiple regression and correlation extensions of the Mantel test of matrix correspondence. Systematic Zoology, 35: 627-632.

Soares, B. E., R. D. Oliveira-Raiol \& L. F. A. Montag. 2011. Occurrence of the non-native blenny Omobranchus punctatus (Valenciennes, 1836) (Perciformes: Blenniidae) in the Amazon coastal zone, Brazil. Aquatic Invasions, 6 (Supplement 1): 39-43.

Soares, B. E., T. O. B. Ruffeil \& L. F. A. Montag. 2012. Occurrence of the non-native sleeper Butis koilomatodon (Bleeker, 1849) (Perciformes: Eleotridae) in the Amazon coastal zone, Brasil. BioInvasions Records, 1: 95-99.

Soyinka, O. O. 2008. The feeding ecology of Mugil cephalus (Linnaeus) from a high brackish tropical lagoon in South-west, Nigeria. African Journal of Biotechnology, 7: 4192-4198.
Wainwright, P. C. \& B. A. Richard. 1995. Predicting patterns of prey use from morphology of fishes. Environmental Biology of Fishes, 44: 97-113.

Wainwright, P. C. 1996. Ecological explanation through functional morphology: the feeding biology of sunfishes. Ecology, 77: 1336-1343.

Wainwright, P. C., D. R. Bellwood \& M. W. Westneat. 2002. Ecomorphology of locomotion in labrid fishes. Environmental Biology of Fishes, 65: 47-62.

Watson, D. J. \& E. K. Balon. 1984. Ecomorphological analysis of fish taxocenes in rainforest streams of northern Borneo. Journal of Fish Biology, 25: 371-384.

Willis, S. C., K. O. Winemiller \& H. Lopez-Fernandez. 2005. Habitat structural complexity and morphological diversity of fish assemblages in a Neotropical floodplain river. Oecologia, 142: 284-295.

Winemiller, K. O. 1991. Ecomorphological diversification in lowland freshwater fish assemblages from five biotic regions. Ecological Monographs, 61: 343-365.

Wolff, L. L. 2012. Assembleias de peixes de um riacho da encosta Atlântica, Brasil: estrutura espacial, uso dos recursos alimentares e relações ecomorfológicas. Unpublished Ph.D. Dissertation, Universidade Estadual de Maringá, Maringá, 94p.

Wootton, R. J. 1994. Ecology of teleost fishes. London, Chapman \& Hall.

Submitted April 16, 2013

Accepted September 10, 2013 by Francisco Gerson Araújo Published December 27, 2013 